\title{
KULEUVEN
}

\section{Identifying ex ante characteristics of Radical Inventions through patent-based indicators}

Dennis Verhoeven, Jurriën Bakker and Reinhilde Veugelers 


\title{
Identifying ex ante characteristics of Radical Inventions through patent-based indicators
}

\author{
Dennis Verhoeven, Jurriën Bakker, Reinhilde Veugelers \\ Managerial Economics, Strategy and Innovation (MSI) \\ Faculty of Business and Economics, KU Leuven
}

May, 2013

\begin{abstract}
With this study we aim at contributing to a better measurement of the ex ante technological dimensions characterizing Radical Inventions. Integrating insights from the existing economics and management literature, we characterize radical inventions ex ante along two dimensions: New Functionality and New Origins. New Functionality regards the extent to which an invention provides substantially new functional capacities. New Origins reflects the extent to which an invention builds on different technological knowledge and principles compared to common practice. These can include technological as well as scientific origins. For each dimension we propose an operationalization using patent classification and citation information. We use a large sample of patent applications to present a first validation exercise. Results indicate that although both dimensions are correlated, each of the indicators proposed convey different information on the ex ante characteristics of Radical Inventions
\end{abstract}

JEL codes: $031,032,033$

* The authors wish to thank S. Graham, D. Guellec, M. Squicciarini, as well as the participants in the GOA-Radical team meetings for their useful inputs. Also participants from workshops at OECD WPIA Meeting (Nov 2012) (Paris), FINKT Summer School (June 2013 Bologna) provided useful comments. Financial support of the Research Council of KULeuven is gratefully acknowledged (GOA/12/003). We are also grateful to ECOOM (Policy Research Center for R\&D Monitoring) for providing us access to the patent and publication data. 


\section{Introduction}

Research on innovation has since long recognized the importance of radical innovation as a crucial element in the process of creative destruction driving economic growth in free market systems (Schumpeter, 1939). The distinction between incremental and radical innovation (RI) resides in the observation of unsteady patterns of development of technologies, markets and industries (Dosi, 1982; Cooper \& Schendel, 1976; Henderson \& Clark, 1990). Failing to participate in or to instigate these abrupt evolvements might threaten growth performance of companies and economies as a whole. Because of these widespread and important implications of radical innovation, it has received and continues to receive attention from a diverse range of scholarly communities (such as economics of innovation, innovation management and evolutionary economics). However, no consensus exists on a clear and stable definition and operationalization of the concept of radical innovation. This impedes warranted generalizability of the results and the development of a comprehensive body of accumulated knowledge surrounding the topic.

In this paper, we aim at contributing to a clear conceptualization of the concept of radical innovation by analyzing and synthesizing existing approaches to define and measure RI. Moreover, we propose three defining conditions of radical innovation along its technological dimensions and propose a patent-based measure for each of them. The remainder of the paper is structured as follows: In the second section of this paper we attempt to sketch a clear picture of how the multi-dimensional concept of radical innovation is defined in the literature. We distinguish between the technological and economic dimensions of the concept. In the third section we detail existing approaches to measuring radical innovation and its characteristics. In the fourth section, we rely on the insights from scholars studying the nature of technology to present three defining conditions of radical innovation along its technological dimensions. We propose three patent-based indicators to measure these conditions and discuss their rationale. In the fifth section, we present a first validation exercise by providing descriptive statistics and performing analyses for how well the indicators predict technological impact, as assessed by the number of patent citations they receive. The sixth and final section discusses the implications of the results, highlights the main limitations and sheds light on avenues for future research.

\section{Defining Radical Innovation}

Reflecting the multitude of angles from which radical innovation is studied, considerable variety exists in the definition of the construct. The lack of a generally established definition results in ambiguity in operationalization (Garcia \& Calantone, 2002). Consequently, a range of labels (discontinuous, breakthrough, new, etc.) is given to phenomena touching upon different dimensions of innovativeness, most of which are operationalized to fit the purpose at hand. The lack of consensus about a framework in which RI should be analyzed, limits the generation of comprehensive empirical findings about the antecedents, nature and impact of RI (Dahlin \& Behrens, 2005).

In this section, we attempt to structure the plethora of definitions by identifying the main angles from which radical innovation is characterized in the literature. Albeit the differences between them, almost all definitions of RI reflect the notion of a break from the past or a large impact on the future along some technological or economic dimension(s) (summarized in table 1).

INSERT TABLE 1 HERE 


\section{Technological dimensions}

Dosi (1982) describes how technology, in similarity with scientific research, evolves along trajectories which are laid out by paradigms that define patterns of problems and ways to address them. Every once in a while, a new paradigm is introduced which opens up avenues for further technological developments. Adhering to this logic as theoretical basis, scholars consider radical innovations as instigators of a new paradigm (e.g. Tripsas, 1997) and often define radical innovation in terms of impact on future technological development. An invention on which many future inventions build is argued to be a breakthrough (Fleming, 2001; Ahuja \& Lampert, 2001) or deemed radical (Schoenmakers \& Duysters, 2010).

Rather than looking at impact, a number of scholars define radical innovation in terms of the characteristics of its underlying technology. Definitions often state that radical innovation incorporates technologies that move away from existing practices (Ettlie et al., 1984; Mascitelli, 2000; Shane, 2001; Dahlin \& Behrens, 2005). A further distinction can be made between studies defining RI in terms of the knowledge that is embodied in the innovation on the one hand, and in terms of its composing elements and architecture on the other. It is argued that RI embeds novel knowledge (Dewar \& Dutton, 1986; Lettl et al., 2006; Carlo et al., 2012) and is based on different scientific and engineering principles compared to existing technology (Henderson \& Clark, 1990). In terms of the elements of which a radical invention consists, definitions state RI combines existing or new components in an unprecedented manner (Nooteboom, 2000; Gassmann \& von Zedtwitz, 2003; Nemet, 2009; Story et al., 2011). It is, however, also argued that radical inventions do not build on any existing technology (e.g. Banerjee \& Cole, 2011).

\section{Economic dimensions}

From an economic viewpoint, radical innovation is often defined in terms of value created by innovative products and changes in market potential. Furthermore, some scholars define RI by the effects it entails on firms' competences and activities, as well as on the industry structure and basis for competition.

From a new product development perspective, radicalness is assessed in terms of product performance increase and newness of product features. Radical innovations have the characteristic of resulting in completely new products (e.g. Wheelwright \& Clark, 1992; Ehrnberg, 1995; de Brentani, 2001; Hurmelinna-Laukkanen et al., 2008; DelgadoVerde et al., 2011; Ritala \& Hurmelinna-Laukkanen, 2013) or products with new performance features (Leifer et al., 2001; Majchrzak et al., 2004; Veryzer, 2005; Lettl et al., 2006), products that incorporate a new technological design (Gassmann \& von Zedtwitz, 2003) or in the birth of a new product class (Rothaermel \& Hill, 2005). Others define radical innovations not in terms of different performance features, but rather in terms of the leap in product performance or price improvements (e.g. Tushman \& Anderson, 1986; Christensen \& Bower, 1996; Leifer et al., 2001). Radical product innovations are also identified as products that redefine prevailing performance criteria (Christensen \& Bower, 1996).

The degree of radicalness is also assessed based on the implications it has for the markets served. A first subdimension occurring in the literature is the extent to which existing sales are replaced by the innovative product through turning obsolete existing products (Cooper \& Schendel, 1972; Delgado-Verde et al., 2011). Furthermore it is argued that radical innovation creates new types of demand, and thus addresses new markets (Henderson \& Clark, 1990; Mascitelli, 2000; Day et al., 2003). Finally, radical innovation is assessed by the degree of newness of an innovation with respect to the market/consumers (Chandy \& Tellis, 1998; Garcia \& Calantone, 2001). 
Applying a firm-level lens, some studies use definitions of radical innovations pertaining to firm's competences and activities. Generally, RI is considered to have important impact on firms' resource and competence base. As such Anderson \& Tushman (1990) distinguish between competence-enhancing and competence-destroying technological discontinuities. Other studies consider the degree of 'newness to the firm' of innovations as a component of the radical innovation construct (e.g. Chandy \& Tellis, 1998; Garcia \& Calantone, 2001) . Necessary knowledge or information leading to or resulting from radical innovations is considered to reside outside the knowledge base present within firms (Dewar \& Dutton, 1986; Hill \& Rothaermel, 2003). Moreover, RI is believed to require significant adaptation of firms' existing routines and activities (Damanpour, 1996; Nahm et al., 2003).

A final, often used approach is to define radicalness in terms of its impact on competition in industries. RI is considered to alter the basis for competition (Anderson \& Tushman, 1990; O'Reilly \& Tushman, 2004) potentially resulting in new entry into the industry (Henderson \& Clark, 1990). It is deemed to drive business growth or development (Veryzer, 2005; Phene et al., 2006) resulting in at least temporary monopoly profits (Mascitelli, 2000). Some authors have also characterized RI in terms of its newness with respect to the entire industry (Garcia \& Calantone, 2001).

\section{Measures of Radical Innovation}

\section{Technology mapping}

As a consequence of the ambiguity in defining RI, a range of different methods to measure RI has been proposed in the literature. A first method maps one or more performance criteria of technologies over time in order to identify inventions that instigate a drastic leap in performance (Tushman \& Anderson, 1986; Anderson \& Tushman, 1990), or to compare competing technological solutions over time as they proceed through their technological life cycle (Christensen \& Bower, 1996). One problem of this method is the difficulty to ex ante select one or more appropriate performance dimension(s) as radical inventions often change performance criteria). Moreover, it is hard to identify which invention can be considered as radical, since often multiple follow-up inventions are needed to gain the performance increase which was caused by implementing the new technology. A third consideration is that analyzing the drivers of technological change requires a more in-depth analysis of the content of the inventions at hand. Moreover, one might even be interested in measuring characteristics of inventions with radical potential, but failed to have a large technological impact. Finally, large-scale empirical analysis is hindered by the time-intensive nature of the method of systematically analyzing and mapping technological progress in order to gather data needed to identify radical innovation. So the rich theory about technological trajectories, S-shaped curves and technological life cycles does not provide clear guidance on the measurement of radicalness of invention on a large scale.

\section{Expert assessment}

A more direct measurement of the dimensions of radical innovations is pursued by using surveys targeting managers or industry experts in order to attain an expert judgment about the radicalness features of a certain technology or product (e.g. Dewar \& Dutton, 1986; Acs \& Audretsch, 1990; Chandy \& Tellis, 2000). A clear advantage of the approach is the possibility to directly gather information from people who can be considered as experts about each dimension identified. Two main problems can be identified with the use of this approach. First, a considerable hindsight bias might exist, favoring those inventions that turned out to be publically identified as important, the ones the respondent is most familiar with or those that are best recalled by the respondent. A second main issue is the 
resource-consuming nature of this approach since true experts might be hard to find or not inclined to respond in detail.

\section{Hedonic price models}

A third approach to identify radical innovations is to use hedonic price models (Henderson \& Clark, 1990; Henderson, 1993). This method consists of decomposing the item being researched into its constituent characteristics, and obtaining estimates of the contributory value of each characteristic. An invention is deemed radical when its content characteristics significantly influence the price markets are willing to pay for it. The advantages of this method are that it is a fairly straightforward way to measure value creation, and that one can easily distinguish between different product characteristics' effects on willingness to pay. However, the results are dependent on the selection of the appropriate criteria (which might be difficult to select ex ante). Furthermore, one can argue that willingness to pay is not an appropriate criterion to assess radical innovation since a small, follow-up invention or minor improvement might result in a dramatic increase in willingness to pay. Finally, this method only allows for identification of RI based on its economic dimensions, hence it does not take into account characteristics related to its technological content.

\section{Patent-based measures}

A fourth major approach applied in the literature for the identification of radical innovation on its technological dimensions is the use of patent-based indicators. Patents provide a detailed, though large-scale assessment of technological progress.

The most widely diffused application of patent-based indicators calculates forward citations in order to assess technological impact (Carpenter, 1981; Fleming, 2001) and (market) value of inventions (Gambardella et al., 2008; Hall et al., 2005). Although it is fairly straightforward to construct and calculate this measure, it has some drawbacks as a measure for radical invention. It is an ex post measure and it does not reflect the characteristics of the invention itself. We argue that technological impact is only one of the possible attributes of a radical invention. First of all, there is the concern of not having direct impact, rather radical innovations might have limited direct impact, but inventions that build on the radical invention might be the ones that receive the impact. Thus, using direct technological impact might assign a high importance to the impactful follow-up invention, while discarding the original invention that was the instigator of the technological developments. This is why we would argue that to gain more insight in the specific characteristics of the inventions that make possible radical technological change, it is important to move to measures that provide information on the technological characteristics of radical inventions. A second issue is that technological impact might be influenced by other factors than the characteristics reflecting radical technological innovation.

Some indicators are proposed to assess (some of the) aforementioned technological dimensions of radical innovation. The number of different technological classes patents cite but not belong to (Shane, 2001), the number of inventors working on the invention (Singh \& Fleming, 2010) and the concentration of patent classes among its backward citations (Trajtenberg et al., 1997) are used to assess the diversity of the knowledge inventions build on, number of backward citations or having no backward citations is used as proxy for the extent to which an invention builds on existing knowledge (Schoenmakers \& Duysters). Both are argued to be a characteristic of radical invention. Furthermore, the number of citations to patents residing from other firms and the number of technological fields occurring for the first time in the patent portfolio are used to reflect the extent to which knowledge is sourced outside the boundaries of the firm (Rosenkopf \& Nerkar, 2001; Ahuja \& Lampert, 2001). Age of the patents cited, 
spread in age (Nerkar, 2003) and the number of references to scientific publications (Gittelman \& Kogut) are argued to be a reflection of novelty of knowledge sources of inventions.

With respect to the technological elements used by inventions, some indicators are proposed to measure the newness of the components/combination of components embodied in the invention. Fleming (2007) measures the occurrence of new combinations of subclasses to which a patent is assigned as a measure of generative creativity of inventors on the patent. Fleming (2001) uses component familiarity/combination of components familiarity (measured by how often and how recent a certain component/combination of components is used before) as a driver of recombinant uncertainty in the creation of breakthrough patents. More recently, topic modeling and semantic patent analysis is used to assess the novelty of the content of inventions.

Dahlin \& Behrens (2005) state that for an invention to be radical, it needs to pass the criteria of novelty, uniqueness and impact. Here, novelty is measured by backward citation patterns of an invention: if a patent has a low overlap in cited documents compared to patents in previous years, it is considered to be novel. Uniqueness is measured similarly by comparing the backward citations of the focal patents to the patents in the same year. Impact is measured by the amount of overlap of patents in the years following the invention and the focal patent. The latter measure is an addition to the construct of technological impact. The main advantage of this approach is that it is one of the first contributions which explicitly conceptualizes radical inventions along a combination of dimensions and attempts to create indicators of each of them separately. The main disadvantage is the computational complexity introduced by comparing sets of citations of each patent to the citations used by every other patent in the population. In this paper we will use a similar approach to conceptualize the concept of radical invention, but will propose a set of different measures to operationalize the construct.

\section{Contribution}

Previous sections synthesized the definitions used in the literature onto separate dimensions and reviewed existing measures used to potentially assess the dimensions identified. Up until now, research has not focused on the development of measures based on a rigorous definition of radical innovation (Dahlin \& Behrens being a notable exception). Moreover, the measures used to identify radical innovation do not provide sufficient coverage of the multidimensional concept, hence hindering generation of generalizable insights pertaining to the drivers and effects

of radical innovation. We aspire to contribute to this gap by proposing three patent-based measures, reflecting three distinct technological dimensions of radical innovation - New Origins, New Functionality and New Impact.

\section{Conceptualization of Radical Invention}

\section{Nature of technology}

We start our conceptualization of radical invention with an explanation about what we mean by technology. Following the work of Arthur $(2007,2009)$ we define technology as being a means to fulfill some human purpose. A technology consists of a number of defining attributes. Each technology embodies a principle (the idea of an effect in use) exploiting some natural phenomenon. Second, in order to translate this principle into physical reality, it consists of components in an architecture that work in relation to each other. Each of these components serves some 
purpose as well, and as such can be defined as a technology itself (or a sub-technology of the higher layer), with its own principle(s) and components. Therefore, technologies can be seen as being recursive, adopting multiple layers of technologies in order to serve some human purpose. The process starting from the identification of some effect to be used in order to serve a human purpose to arrive at a reliable/highly performing exploitation of this effect is usually a lengthy one. This is because the conversion of a principle of use into a working technology consists of multiple problem sequences that aim at solving requirements in terms of its components and the relationship between these components (which themselves might pose problems of their own). Similar patterns are described by the seminal work of Dosi (1982), labeling them paradigms and technological trajectories. It is argued that each technology also embodies knowledge about its components, architecture and workings, and that along trajectories, knowledge related to the principle, components, architecture and its actual workings are accumulated. Having provided the meaning of technology in this context, we know turn to how we define radical invention.

Radical invention includes the introduction of new concepts based on a different set of principles that depart significantly from past practices (new origins). It provides new functional capacities which are a discontinuity with prevailing capabilities (new functionality). It serves as the basis for new potential applications (new impact).

Based on this definition we identify three conditions that characterize radical invention. For each of these three characterizing definitions, we propose an indicator based on patent classification and citation information. The International Patent Classification (IPC) is a hierarchical system of classification for all patents. Classes mainly reflect the purpose and/or the components and methods used in a patented invention. Usually a patent is classified into more than one technological class. Similar to citations between scientific papers, patents also include citations to prior art (given by the applicant or the patent examiner). Citations are used to provide the background of the patented invention and also serve as legal mechanism to limit the citing patent's scope. Citations are thus an indicator of relatedness (of content) between the patents. The indicators proposed will utilize pairwise cooccurrence of classes to which a patent is assigned, as well as pairwise combinations of classes from patents that are linked through a citation.

\section{New Origins}

Our first condition states that a radical invention is based on knowledge that originates from a technological domain different from the technological domain the invention applies to. In so doing, it brings new knowledge to the means of fulfilling a particular human purpose. This condition relates to the principles used in a technology and its subtechnologies. When a way of serving some purpose embodies one or more new principles of use, it is very likely that the knowledge an invention relies on, draws knowledge from fields and technologies (or sub-technologies) that the existing practices do not rely on.

Our indicator proposed to measure New Origins uses backward citations to capture information on the extent to which an invention builds on new technological knowledge and principles. It relies on the assumption that if an invention builds on knowledge that is usually not built on by inventions in its technological domain, it will cite one or more patents that are classified into one or more classes that were never cited before by patents in the focal patent's class. Hence, it counts the number of new combinations of technology classes created by citations from the focal patent to other patents. So if a patent from class A cites a patent from class B, and if no patent of class $A$ has ever cited a patent of class B, the patent's score on this indicator is incremented by one. In short, the indicator measures the number of new technological class pairs created through the backward citations of a patent.

\section{New Functionality}


Our second condition states that radical invention implies a functionality that is different from prevailing capabilities. This condition relates to the components/architecture used in the technology, as well as the application the invention has. It includes that we deem inventions as having new functionality if it uses new combinations of components for some application and/or generates new applications for a set of components.

Following Fleming (2007), we propose to measure New Functionality using the different technological classes patents are assigned to. It relies on the assumption that if a patent uses different components to serve a purpose, and/or uses similar components to serve a different purpose, its classification will reflect this by involving a combination of classes that were never used before together. This indicator counts the number of new pairwise combinations of technological classes a patent is assigned to. So if a patent is assigned to class $A$ and class $B$, and if no other patent is classified into class $A$ and $B$ simultaneously before, the patent scores on this indicator.

\section{New Impact}

Finally we state that radical inventions serve as the basis for follow-up inventive effort. Instead of following the definition often applied that identifies radical inventions in terms of their cumulative technological impact, we apply a different condition. We consider those inventions that serve as the basis for follow-up inventive effort in fields that have never before used knowledge and principles from the field of the focal invention. In other words, the invention with new impact relates for the first time two previously disconnected technological fields.

In concordance with the measure for New Origins, we devise the measure for New Impact by quantifying the extent to which inventions from technological fields that were previously not building on the technological field of the invention, build on the focal invention. If a patent is used as a source for subsequent inventions in different technological domains, we assume that this will be reflected by citations from patents in technological classes that have never before cited the classes of the focal patent. We count the number of new combinations of technology classes created by citations from other patents to the focal patent. If a patent from class $A$ is cited by a patent from

class B, and if no patent of class B has ever cited a patent from class A, the focal patent's score on our New Impact indicator is incremented by one. Hence, the indicator measures the number of new technological class pairs created through the received citations of a patent.

The first two dimensions - New Origins and New Functionality - identify ex ante characteristics of RI. They pertain to characteristics of the content of inventions and do not place conditions on its effects. The third dimension - New Impact - adds a condition on the effects an invention entails on follow-up inventive effort and therefore is an ex post determined measure. For certain research questions, interest might lie in an ex ante identification of inventions that carry the characteristics RI, regardless of their actual effects. While we state RI is only fully identified when it fulfills all three criteria outlined, we take a broad stance toward this issue and use both the 'ex-ante criterion', as well as the 'full criterion' to identify RI in the validation exercise.

\section{Validation}

In this section we present our first validation exercises with respect to the introduced measures. First, we discuss the dataset used and detail the calculation of the indicators. Second we present correlations among the measures created to verify to what extent they are complementary in information they convey about the invention. Third, we analyze how our indicators correlate to a measure using the number of citations received by a patent as a measure of technological impact. 


\section{Data}

Sample

The sample includes all patent applications filed at the European Patent Office (EPO), US Patent and Trademark Office (USPTO) and World Intellectual Property Office (WIPO) (the latter includes patents that were filed using the Patent Cooperation Treaty, also referred to as the PCT-route). To minimize truncation issues related to the difference in time patents have to receive citations, we only include patents between 1980 and 1995 . So every patent application had at least 15 years to be cited. Given that patents generally receive the bulk of their forward citations within the first years after publication, we are confident that this type of censoring will not bias the results. All forward citation counts are corrected for families using the DOCDB family definition (Martinez, 2010). Furthermore, for the forward citation analysis we exclude all patents that did not receive any citation in order to increase comparability between the patents that score on New Impact (requires at least one citation) and those that do not. This leaves us with a total sample of 2297499 patent applications.

New Origins - New Functionality - New Impact

We constructed our measure of New Origins based on every patent application and their classification into IPC classes. We made use of the IPC-classes on the 4-digit and 6-digit level of aggregation ${ }^{1}$. For every application (from 1970 onwards), we extracted backward citations and the class codes of every cited application. This information is used to construct combinations of classes defined by every citation pair. For every application in the sample the combinations made through its backward citations are compared to all such combinations made by applications filed in all previous years. For every new combination introduced by the focal application, we increment the measure of New Origins by one. For every application we create a dummy indicating whether it scored at least one on this measure. On the 4-digit level about 1 percent of the applications score on New Origins while on the 6-digit level about 22 percent of the applications score.

The calculation of the indicator for New Functionality again uses IPC-classification (again on the 4-digit and 6-digit levels) information, but combinations are now defined by co-occurrence of IPC-classes on one and the same patent application. For every application we constructed each pairwise combination of patent classes it is assigned to and compared the combinations to all combinations occurring in the years previous to the application filing date of the focal patent. This results in a count of new class combinations, which we transform to a dummy variable indicating the use of at least one new combination. Patent applications scoring on this measure at the 4-digit and 6-digit reflect 0.15 percent and 2.5 percent of our sample respectively.

Similarly to the New Origins indicator, the measure for New Impact was constructed using patent class and citation information. In this case we used new combinations made by forward citations to the focal patent and incremented by one the indicator every time the application is cited by another application whereby a new combination of classes is occurring for the first time. Respectively approximately 0.7 and 23 percent of the applications in our sample score at least one on New Impact.

We also construct a composite measure (Radical) that receives a value of 1 if the patent scores on every of our three measures. Finally, we construct an indicator measuring RI on its ex-ante criteria (Radical ex ante) which receives a value of 1 if the invention scores at least on New Origins and New Functionality.

\footnotetext{
${ }^{1}$ The IPC-classification scheme consists of 5 levels of aggregation. The aggregation levels we use respectively contain 637 and about 8000 classes
} 


\section{Internal correlations}

Table 2 presents bivariate correlations between all measures devised. All correlations are significant at the 1 percent level, but generally do not amount to more than 0.3 for the indicators reflecting our three dimensions separately. This finding confirms that the three indicators proposed are not measuring one and the same construct, and strengthens our intuition about the conceptualization of radical invention as a multi-dimensional concept. One exception is the high correlation between the composite measures (Ex-Ante Radical and Radical) and New Functionality at the 6 digit level. This means that patents scoring on the indicator for New Functionality to a large extent also score on the other two indicators, indicating that the 6 digit level of calculation might be too disaggregate. Figure 1 presents a Venn-diagram of patent applications scoring at least on one of our indicators. Again, we see that the indicators convey different information since for each dimension, a considerable amount of patents only scores on that dimension whereas relatively few inventions score on all three indicators.

\section{INSERT TABLE 2 AND FIGURE 1 HERE}

\section{Citation analysis}

Technological breakthroughs are defined as those inventions that are an outlier in terms of impact on future inventive effort (Fleming, 2001). Although we do not put forward that high, cumulative technological impact is a defining condition of radical innovation, we would expect inventions that we identify as having New Origins, New Functionality and New Impact have higher likelihood of large technological impact, as well as a higher variety. This is why we perform an analysis that investigates whether inventions, identified as radical through our measures, have an above average likelihood to become breakthroughs. We also present summary statistics of the number of forward citations received, conditional on scoring on our indicators.

\section{Technological impact}

As a first measure of technological impact we use the number of forward citations (corrected for families, see above) that a patent received. Second, we compose a dummy variable reflecting whether a patent belongs to the upper end of the forward citation distribution (if it is a 5 standard deviation outlier).

\section{Controls}

In line with previous studies that use patent information to predict technological impact, we identify a number of control variables that might be related to the probability of being highly cited. We calculate the number of backward citations to patents since this is argued to be an indicator of the extent to which an invention builds on previous knowledge (Schoenmakers \& Duysters, 2010). We also devise measures for the number of IPC-classes (on a 3, 4 and 6-digit level) a patent is assigned to since it is shown to be related to the probability of breakthrough invention (Arts, 2013). We include the size of the DOCDB family reflecting the number of equivalent documents of the patent. Finally we also control for the number of applicants and inventors of each patent. Finally, we included year dummies to control for effects attributable to the year of the patent application.

\section{Conditional descriptive statistics}


About 0.9 percent (about 20000) of the patents in our sample was a breakthrough at the 5 standard deviation level. Table 4 presents these summary statistics conditional on scoring on our indicators. Patents scoring at our indicators are more likely to be a breakthrough than those that do not. Moreover, patents scoring on all three indicators of our indicators are even more likely to receive high impact than those scoring only on one or two. We also see a difference between breakthrough likelihood of our measures calculated on the 4 digit and 6 digit level. These results seem to suggest that the higher level of aggregation is more appropriate to predict probability of breakthrough. A similar pattern can be observed when comparing means and standard deviations of forward citation counts.

INSERT TABLE 3 AND TABLE 4 HERE

\section{Multivariate analyses}

We ran logit regressions with the binary variable of our breakthrough measure as dependent, and variables reflecting our indicators, as well as our set of controls as independent variables (table 5). Model 1 includes all control variables, model 2 until 5 includes New Origins, New Functionality and New Impact (on IPC4 level) respectively. Model 6 includes all measures identified and in model 7 to 11 we repeated this on the IPC6 levels. With respect to our control variables, we find positive and significant effects of number of IPC4 classes, number of family members, number of inventors and the number of backward citations. Negative effects are observed for the number of IPC3 classes and the number of applicants. With respect to the indicators at the IPC4 level, we find every indicator to have a significant and positive effect on the probability of a patent to become a breakthrough. However, we do not find that the combination of our dimensions adds to the separate effects combined (Model 6). In accordance with the findings from the descriptive statistics, we find a lower effect of our indicators on the IPC6 level and the indicator for New Origins even has a negative value. As a robustness check, we ran the same analyses for a more stringent condition on the number of forward citations demanded to be a breakthrough (10 SD outlier measure) and find qualitatively similar results. Only using the sample of USPTO patents (as is often done in previous studies, e.g. Trajtenberg et al., 1997) did not alter the results substantially.

INSERT TABLE 5 HERE

\section{Discussion and Conclusion}

Having analyzed and synthesized the existing literature on the definition and measurement of radical innovation, we identified a number of economic and technological dimensions along which the construct is defined and measured. Using insights from scholars who study the nature and evolution of technological development (e.g. Arthur, 2007), we detailed three defining conditions of radical invention and proposed patent-based indicators for measuring them. Results from an initial validation exercise indicate the measures composed are measuring different concepts and do not correlate highly with a number of patent-based already measures used in the literature. This result stems us positive regarding our conceptualization of radical invention as having three distinct dimensions.

The results from the differences in mean number of forward citations received, as well as probability of being a breakthrough conditional on scoring on the indicators give a first indication that the indicators relate to technological impact. Moreover, we find these effects to be strongest when using measures on a higher aggregation level of technological classification. These results are less strong, but hold when controlling for a number of variables that are argued to explain technological impact. Important to note, however, is that we do not put forward technological 
impact as a soundproof validation criterion of radicalness. Direct technological impact is only expected to be a possible effect of radical inventions. Important to note is that inventions with radical characteristics might be a basis for further technological progress which include refinements and applications of the principles and knowledge introduced. It is plausible that these follow-up inventions might have a higher direct technological impact. Furthermore, using knowledge from different origins and applying new principles can be considered as risky. Consequently, one would expect a large proportion of inventions having these characteristics to fail. Depending on the research question, one might want to also identify these failed inventions. In sum, the major limitation of this validation approach is that it is hard to identify the coefficients one would see if the indicators would perfectly reflect the underlying dimensions that they aim to measure.

In conclusion, this study can be seen as a first step in the creation of reliable indicators for measuring distinct technological dimensions of radical innovation. Future work will include more direct validation approaches and refinements of the indicators. This will entail a comparison between the indicators presented and indicators proposed in the existing literature. We envision relying on industry experts to separately score inventions on the dimensions identified in order to directly validate each indicator with respect to the dimension it is put forward to measure. Refinements of the indicators might include the use of a weighting scheme reflecting technological proximity of the new combinations made by patents or the use of cluster analysis to redefine existing technological classes based on co-occurrence and co-citation patterns. 
Tables

\begin{tabular}{|c|c|c|c|c|c|c|c|c|c|}
\hline & \multicolumn{3}{|c|}{ Technological dimensions } & \multicolumn{6}{|c|}{ Economic dimensions } \\
\hline Author(s) & $\begin{array}{l}\text { Impact on future } \\
\text { technological } \\
\text { practices }\end{array}$ & $\begin{array}{l}\text { Knowledge embodied } \\
\text { in the invention }\end{array}$ & $\begin{array}{l}\text { New elements/ } \\
\text { elements combined } \\
\text { in a novel way }\end{array}$ & $\begin{array}{l}\text { New products/ } \\
\text { applications }\end{array}$ & $\begin{array}{l}\text { Product } \\
\text { performance } \\
\text { increase }\end{array}$ & $\begin{array}{l}\text { Market } \\
\text { impact }\end{array}$ & $\begin{array}{l}\text { Impact on firm's } \\
\text { competences }\end{array}$ & $\begin{array}{c}\text { Impact on firm's } \\
\text { activities }\end{array}$ & Impact industry \\
\hline Cooper \& Schendel ,1976 & & & & & & \begin{tabular}{|c|}
$\begin{array}{c}\text { Impact on sales } \\
\text { of existing } \\
\text { products }\end{array}$ \\
\end{tabular} & & & \\
\hline Dosi ,1982 & $\begin{array}{c}\text { Newly introduced } \\
\text { paradigm }\end{array}$ & & & & & & & & \\
\hline $\begin{array}{c}\text { Ettlie, Bridges, O'keefe, } \\
1984\end{array}$ & & \begin{tabular}{|l|} 
Incorporates technology \\
that is departure from \\
'existing practices' \\
\end{tabular} & & & & & & & \\
\hline $\begin{array}{l}\text { Tushman \& Anderson, } 1986 \\
\text { Anderson \& Tushman, } 1990\end{array}$ & & & & & $\begin{array}{c}\text { Sharp } \\
\text { price/performance } \\
\text { improvements }\end{array}$ & & $\begin{array}{c}\text { Competence- } \\
\text { enhancing/destroying }\end{array}$ & & $\begin{array}{l}\text { Instigate } \\
\text { Technological } \\
\text { uncertainty }\end{array}$ \\
\hline Dewar \& Dutton, 1986 & & $\begin{array}{c}\text { Degree of novel } \\
\text { technological process } \\
\text { content/knowledge } \\
\text { embodied in the } \\
\text { innovation } \\
\end{array}$ & & & & & $\begin{array}{l}\text { Require firms to } \\
\text { process new } \\
\text { information }\end{array}$ & & \\
\hline Henderson \& Clark, 1990 & & $\begin{array}{c}\text { Different set of } \\
\text { scientific/engineering } \\
\text { principles }\end{array}$ & & $\begin{array}{l}\text { New potential } \\
\text { applications }\end{array}$ & & $\begin{array}{l}\text { Often open up } \\
\text { new markets }\end{array}$ & & & $\begin{array}{l}\text { Potential basis for } \\
\text { new entrants }\end{array}$ \\
\hline Wheelwright \& Clark, 1992 & & & & $\begin{array}{l}\text { Significant changes to } \\
\text { products/processes }\end{array}$ & & & & & \\
\hline Ehrnberg, 1995 & & & & $\begin{array}{l}\text { Physical changes in } \\
\text { product/process }\end{array}$ & $\begin{array}{l}\text { Price/performance } \\
\text { change }\end{array}$ & & $\begin{array}{l}\text { Technical } \\
\text { competences and } \\
\text { other resources }\end{array}$ & & \\
\hline Christensen \& Bower, 1996 & & & & & $\begin{array}{c}\text { Disrupt an } \\
\text { established } \\
\text { trajectory of } \\
\text { performance } \\
\text { improvement, or } \\
\text { rede- } \\
\text { fine what } \\
\text { performance means }\end{array}$ & & & & \\
\hline Damanpour, 1996 & & & & & & & & \begin{tabular}{|c|} 
Fundamental \\
changes in firm's \\
activities, departing \\
significantly from \\
existing practices
\end{tabular} & \\
\hline
\end{tabular}




\begin{tabular}{|c|c|c|c|c|c|c|c|c|c|}
\hline \multirow[b]{2}{*}{ Author(s) } & \multicolumn{3}{|c|}{ Technological dimensions } & \multicolumn{6}{|c|}{ Economic dimensions } \\
\hline & $\begin{array}{l}\text { Impact on future } \\
\text { technological } \\
\text { practices }\end{array}$ & $\begin{array}{l}\text { Knowledge embodied } \\
\text { in the invention }\end{array}$ & $\begin{array}{l}\text { New elements/ } \\
\text { elements combined } \\
\text { in a novel way }\end{array}$ & $\begin{array}{l}\text { New products/ } \\
\text { applications }\end{array}$ & $\begin{array}{l}\text { Product } \\
\text { performance } \\
\text { increase }\end{array}$ & $\begin{array}{l}\text { Market } \\
\text { impact }\end{array}$ & $\begin{array}{l}\text { Impact on firm's } \\
\text { competences }\end{array}$ & $\begin{array}{c}\text { Impact on firm's } \\
\text { activities }\end{array}$ & Impact industry \\
\hline Tripsas, 1997 & New paradigm & & & & & & & & \\
\hline Chandy \& Tellis, 1998 & & & & & & $\begin{array}{c}\text { New to the } \\
\text { market }\end{array}$ & $\begin{array}{l}\text { Innovation new to the } \\
\text { firm }\end{array}$ & & \\
\hline Nooteboom, 2000 & & & $\begin{array}{c}\text { Architectural: entails } \\
\text { new combination of } \\
\text { activities or elements } \\
\text { from previously } \\
\text { disconnected }\end{array}$ & & & & & & \\
\hline Mascitelli, 2000 & & $\begin{array}{l}\text { Involve significantly new } \\
\text { technologies }\end{array}$ & & & & $\begin{array}{c}\text { New market } \\
\text { with respect to } \\
\text { product class }\end{array}$ & & & \begin{tabular}{|c} 
At least temporary \\
monopoly \\
profits/significant \\
increase in market \\
share
\end{tabular} \\
\hline Fleming, 2001 & Number of technologies & & & & & & & & \\
\hline Shane, 2001 & & $\begin{array}{l}\text { Degree to which an } \\
\text { invention differs from } \\
\text { previous ones/ New } \\
\text { approach to technical } \\
\text { practice } \\
\end{array}$ & & & & & & & \\
\hline Rosenkopf \& Nerkar, 2001 & $\begin{array}{l}\text { Impact on future } \\
\text { technologies }\end{array}$ & & & & & & & & \\
\hline de Brentani, 2001 & & & & Newness of the product & & & & & \\
\hline Ahuja \& Lampert, 2001 & $\begin{array}{l}\text { Breakthrough if a lot of } \\
\text { subsequent inventions } \\
\text { build on it }\end{array}$ & & & & & & & & \\
\hline $\begin{array}{l}\text { Leifer, O'Connor, Rice, } \\
\qquad 2001\end{array}$ & & & & $\begin{array}{c}\text { Unprecedented } \\
\text { performance features }\end{array}$ & $\begin{array}{c}\text { Significant } \\
\text { improvement in } \\
\text { performance or cost }\end{array}$ & & & & \\
\hline Garcia \& Calantone, 2002 & & & & & & \begin{tabular}{|c|} 
New to the \\
market (macro)/ \\
consumers of \\
the firm (micro)
\end{tabular} & $\begin{array}{l}\text { New to the firm } \\
\text { (micro) }\end{array}$ & & $\begin{array}{l}\text { New to the } \\
\text { industry (macro) }\end{array}$ \\
\hline
\end{tabular}

Table 1 (Ctd): Overview definitions Radical Innovation 


\begin{tabular}{|c|c|c|c|c|c|c|c|c|c|}
\hline & \multicolumn{3}{|c|}{ Technological dimensions } & \multicolumn{6}{|c|}{ Economic dimensions } \\
\hline Author(s) & $\begin{array}{l}\text { Impact on future } \\
\text { technological } \\
\text { practices }\end{array}$ & $\begin{array}{l}\text { Knowledge embodied } \\
\text { in the invention }\end{array}$ & $\begin{array}{l}\text { New elements/ } \\
\text { elements combined } \\
\text { in a novel way }\end{array}$ & $\begin{array}{l}\text { New products/ } \\
\text { applications }\end{array}$ & $\begin{array}{l}\text { Product } \\
\text { performance } \\
\text { increase }\end{array}$ & $\begin{array}{l}\text { Market } \\
\text { impact }\end{array}$ & $\begin{array}{l}\text { Impact on firm's } \\
\text { competences }\end{array}$ & $\begin{array}{c}\text { Impact on firm's } \\
\text { activities }\end{array}$ & Impact industry \\
\hline Hill \& Rothaermel, 2003 & & & & & & & \begin{tabular}{|c|} 
Newness of \\
technology to the firm
\end{tabular} & & \\
\hline $\begin{array}{l}\text { Nahm, Vonderembse, } \\
\text { Koufteros, } 2003\end{array}$ & & & & & & & & $\begin{array}{l}\text { Basic changes in } \\
\text { the task system }\end{array}$ & \\
\hline $\begin{array}{c}\text { Gassmann \& von Zedtwitz, } \\
2003\end{array}$ & & $\begin{array}{c}\text { New Technology or } \\
\text { integration of formerly } \\
\text { unrelated technology for } \\
\text { novel applications }\end{array}$ & & $\begin{array}{l}\text { New technological } \\
\text { design }\end{array}$ & & New markets & & & \\
\hline $\begin{array}{l}\text { Day, Fein, Ruppersberger, } \\
2003\end{array}$ & & & & \begin{tabular}{|c|}
$\begin{array}{c}\text { New products or services } \\
\text { not possible without the } \\
\text { technology }\end{array}$ \\
\end{tabular} & & New markets & & & \\
\hline $\begin{array}{l}\text { Majchrzak, Cooper, Neece, } \\
2004\end{array}$ & & & & $\begin{array}{c}\text { Unprecedented } \\
\text { performance features }\end{array}$ & $\begin{array}{c}\text { Unprecedented } \\
\text { performance } \\
\text { increase } \\
\end{array}$ & & & & \\
\hline O'Reilly \& Tushman, 2004 & & & & & & & & & $\begin{array}{l}\text { Altered basis for } \\
\text { competition }\end{array}$ \\
\hline Rothaermel \& Hill, 2005 & & & & $\begin{array}{c}\text { New product } \\
\text { (classes)/processes }\end{array}$ & $\begin{array}{l}\text { Highly increased } \\
\text { performance }\end{array}$ & & & & \\
\hline Veryzer, 2005 & & & & $\begin{array}{c}\text { Unprecedented } \\
\text { performance features }\end{array}$ & & & & & $\begin{array}{c}\text { New lines of } \\
\text { business }\end{array}$ \\
\hline Dahlin \& Behrens, 2005 & $\begin{array}{l}\text { Impact on future } \\
\text { technologies }\end{array}$ & $\begin{array}{l}\text { Novelty and uniqueness of } \\
\text { invention }\end{array}$ & & & & & & & \\
\hline $\begin{array}{l}\text { Phene, Fladmoe-Lindquist, } \\
\text { Marsh, } 2006\end{array}$ & $\begin{array}{l}\text { Challenge the existing } \\
\text { technological order and } \\
\text { shape new trajectories }\end{array}$ & & & & & & Corporate reinvention & & $\begin{array}{l}\text { Business growth } \\
\text { and new business } \\
\text { development }\end{array}$ \\
\hline $\begin{array}{l}\text { Lettl, C; Herstatt, } \\
\text { Gemuenden, } 2006\end{array}$ & & $\begin{array}{c}\text { Knowledge about } \\
\text { components or } \\
\text { architecture differs } \\
\text { significantly from existing } \\
\text { knowledge }\end{array}$ & & $\begin{array}{l}\text { Satisfies unmet needs for } \\
\text { first time and result in } \\
\text { quantum leap in } \\
\text { consumer value }\end{array}$ & & & & & \\
\hline
\end{tabular}

Table 1 (Ctd): Overview definitions Radical Innovation 


\begin{tabular}{|c|c|c|c|c|c|c|c|c|c|}
\hline & \multicolumn{3}{|c|}{ Technological dimensions } & \multicolumn{6}{|c|}{ Economic dimensions } \\
\hline Author(s) & $\begin{array}{c}\text { Impact on future } \\
\text { technological } \\
\text { practices }\end{array}$ & $\begin{array}{c}\text { Knowledge embodied } \\
\text { in the invention }\end{array}$ & $\begin{array}{l}\text { New elements/ } \\
\text { elements combined } \\
\text { in a novel way }\end{array}$ & $\begin{array}{l}\text { New products/ } \\
\text { applications }\end{array}$ & $\begin{array}{c}\text { Product } \\
\text { performance } \\
\text { increase }\end{array}$ & $\begin{array}{l}\text { Market } \\
\text { impact }\end{array}$ & $\begin{array}{l}\text { Impact on firm's } \\
\text { competences }\end{array}$ & $\begin{array}{c}\text { Impact on firm's } \\
\text { activities }\end{array}$ & Impact industry \\
\hline $\begin{array}{l}\text { Hurmelinna-Laukkanen, } \\
\text { Sainio, Jauhiainen, } 2008\end{array}$ & & & & Completely new product & & & & & \\
\hline Nemet, 2009 & & & New connections & $\begin{array}{l}\text { Minor relatedness to } \\
\text { existing products }\end{array}$ & & & & & \\
\hline $\begin{array}{c}\text { Schoenmakers \& Duysters, } \\
2010\end{array}$ & $\begin{array}{c}\text { Relatively many } \\
\text { subsequent inventions } \\
\text { build on }\end{array}$ & & & & & & & & \\
\hline $\begin{array}{l}\text { Delgado-Verde, Navas- } \\
\text { Lopez, Cruz-Gonzalez, } \\
\text { Amores-Salvado, } 2011 \\
\end{array}$ & & & & $\begin{array}{c}\text { Completely new } \\
\text { innovations/ degree of } \\
\text { novelty }\end{array}$ & & $\begin{array}{l}\text { Turn obsolete } \\
\text { prevailing } \\
\text { products }\end{array}$ & & & \\
\hline Banerjee \& Cole, 2011 & & & $\begin{array}{l}\text { Build on no existing } \\
\text { technology (global) }\end{array}$ & & & & \begin{tabular}{|c|}
$\begin{array}{c}\text { Build on prior } \\
\text { knowledge outside the } \\
\text { firm (local) }\end{array}$ \\
\end{tabular} & & \\
\hline Story, O'Malley, Hart, 2011 & & & $\begin{array}{l}\text { Technological } \\
\text { radicalness }\end{array}$ & $\begin{array}{c}\text { Degree of innovativeness } \\
\text { to consumer }\end{array}$ & & & & & \\
\hline $\begin{array}{l}\text { Carlo, JL; Lyytinen, K; Rose, } \\
2012\end{array}$ & & $\begin{array}{c}\text { Products resulted from } \\
\text { acquiring, assimilating, } \\
\text { and exploiting unique and } \\
\text { novel knowledge of a firm }\end{array}$ & & & & & & & \\
\hline $\begin{array}{l}\text { Ritala \& Hurmelinna- } \\
\text { Laukkanen, } 2013\end{array}$ & & & & $\begin{array}{l}\text { Completely new } \\
\text { products/services }\end{array}$ & & & & & \\
\hline
\end{tabular}

Table 1 (Ctd): Overview definitions Radical Innovations

\begin{tabular}{|c|c|c|c|c|c|c|c|c|c|c|}
\hline & $\begin{array}{l}\text { New } \\
\text { Origins } \\
\text { (IPC4) }\end{array}$ & $\begin{array}{l}\text { New } \\
\text { Functionality } \\
\text { (IPC4) }\end{array}$ & $\begin{array}{l}\text { New } \\
\text { Impact } \\
\text { (IPC4) }\end{array}$ & $\begin{array}{l}\text { Ex-Ante } \\
\text { Radical } \\
\text { (IPC4) }\end{array}$ & $\begin{array}{l}\text { Composite } \\
\text { measure } \\
\text { Radical } \\
\text { (IPC4) }\end{array}$ & $\begin{array}{l}\text { New } \\
\text { Origins } \\
\text { (IPC6) }\end{array}$ & $\begin{array}{c}\text { New } \\
\text { Functionality } \\
\text { (IPC6) }\end{array}$ & $\begin{array}{l}\text { New } \\
\text { Impact } \\
\text { (IPC6) }\end{array}$ & $\begin{array}{c}\text { Ex-Ante } \\
\text { Radical (IPC6) }\end{array}$ & $\begin{array}{c}\text { Composite } \\
\text { measure } \\
\text { Radical } \\
\text { (IPC6) }\end{array}$ \\
\hline $\begin{array}{l}\text { New Origins } \\
\text { (IPC4) }\end{array}$ & 1 & & & & & & & & & \\
\hline $\begin{array}{l}\text { New Functionality } \\
\text { (IPC4) }\end{array}$ & $0.12 *$ & 1 & & & & & & & & \\
\hline $\begin{array}{l}\text { New Impact } \\
\text { (IPC4) }\end{array}$ & $0.1176^{*}$ & $0.0981^{*}$ & 1 & & & & & & & \\
\hline $\begin{array}{l}\text { Ex-Ante Radical } \\
\text { (IPC4) }\end{array}$ & $0.2158^{*}$ & $0.5672^{*}$ & $0.0943^{*}$ & 1 & & & & & & \\
\hline \multicolumn{11}{|l|}{ Composite measure } \\
\hline $\begin{array}{l}\text { Radical } \\
\text { (IPC4) }\end{array}$ & $0.1359 *$ & $0.3572^{*}$ & $0.1517^{*}$ & $0.6293 *$ & 1 & & & & & \\
\hline $\begin{array}{l}\text { New Origins } \\
\text { (IPC6) }\end{array}$ & $0.188^{*}$ & $0.0596^{*}$ & $0.0807 *$ & $0.0406 *$ & $0.0256^{*}$ & 1 & & & & \\
\hline
\end{tabular}




\begin{tabular}{|c|c|c|c|c|c|c|c|c|c|c|}
\hline $\begin{array}{l}\text { New Functionality } \\
\text { (IPC6) }\end{array}$ & $0.0955^{*}$ & $0.2277^{*}$ & $0.0793^{*}$ & $0.1292^{*}$ & $0.0813^{*}$ & $0.2257^{*}$ & 1 & & & \\
\hline $\begin{array}{l}\text { New Impact } \\
\text { (IPC6) }\end{array}$ & $0.0895^{*}$ & $0.0495 *$ & $0.1593^{*}$ & $0.0322 *$ & $0.0242 *$ & $0.3051 *$ & $0.1846 *$ & 1 & & \\
\hline $\begin{array}{l}\text { Ex-Ante Radical } \\
\text { (IPC6) }\end{array}$ & $0.1119 *$ & $0.2243^{*}$ & $0.0833^{*}$ & $0.1467 *$ & $0.0923 *$ & $0.2768^{*}$ & $0.8807^{*}$ & $0.1861 *$ & 1 & \\
\hline \multicolumn{11}{|l|}{ Composite measure } \\
\hline $\begin{array}{l}\text { Radical } \\
\text { (IPC6) }\end{array}$ & $0.1122^{*}$ & $0.2134 *$ & $0.0972^{*}$ & $0.1457^{*}$ & $0.1048^{*}$ & $0.2439 *$ & $0.7761^{*}$ & $0.2307^{*}$ & $0.8813^{*}$ & 1 \\
\hline
\end{tabular}

Table 2: Correlations between variables, * indicates $p<0.01$

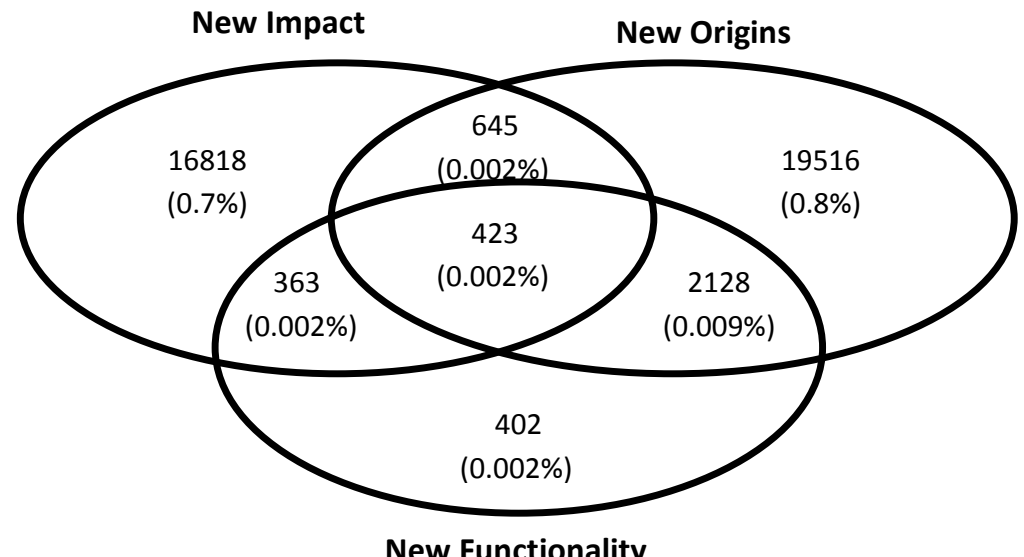

299

New Functionality

Figure 1: Venn-diagrams patent applications scoring on indicators calculated on IPC4 (left) and IPC6 (right) 


\begin{tabular}{cc}
\hline \hline Variable name & $\begin{array}{c}\text { Mean (Standard } \\
\text { Deviation) }\end{array}$ \\
\hline \hline Forward citations & $15,42(24,23)$ \\
Breakthrough dummy & 0.0087 \\
New Origins (IPC4) & 0.0099 \\
New Functionality (IPC4) & 0.0014 \\
New Impact (IPC4) & 0.0079 \\
Composite measure Radical (IPC4) & 0.0002 \\
New Origins (IPC6) & 0.2201 \\
New Functionality (IPC6) & 0.0271 \\
New Impact (IPC6) & 0.2398 \\
Composite measure Radical (IPC6) & 0.0165 \\
Number of IPC3 classes & $1,58(0,83)$ \\
Number of IPC4 classes & $1,86(1,15)$ \\
Number of IPC6 classes & $2,59(2,11)$ \\
Number of DoCDB family members & $4,78(4,81)$ \\
Number of applicants & $1,12(0,54)$ \\
Number of inventors & $2,13(1,51)$ \\
Number of backward citations & $7,72(8,07)$ \\
\hline \hline
\end{tabular}

Table 2: Descriptive statistics

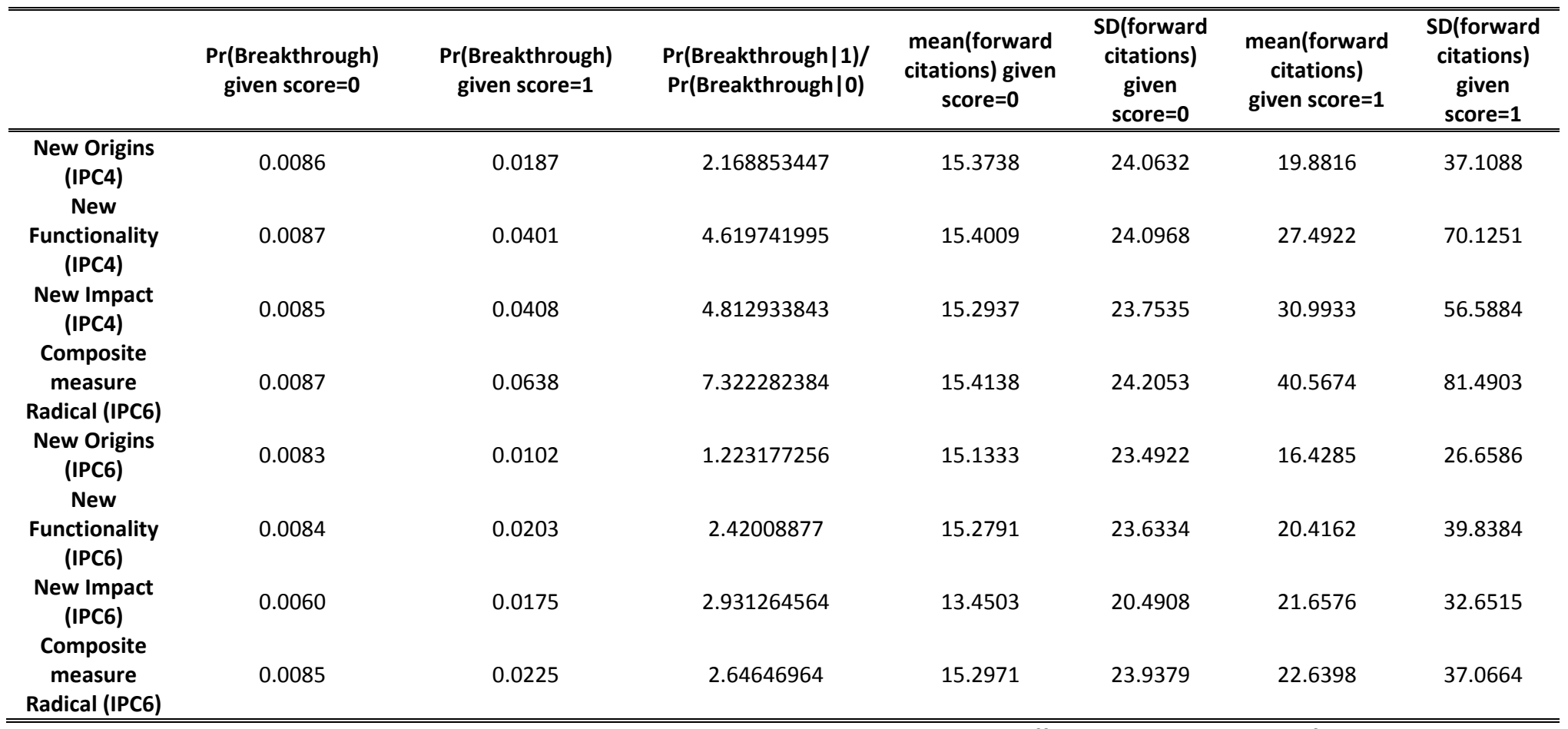

Table 4: Means and standard deviations conditional on scoring on the indicators, all differences in means are significant at the 1 percent confidence level ( $p$-value $<0.01$ ) 


\begin{tabular}{|c|c|c|c|c|c|c|c|c|c|c|c|}
\hline Variable & 1 & 2 & 3 & 4 & 5 & 6 & 7 & 8 & 9 & 10 & 11 \\
\hline \multirow[t]{2}{*}{ New Origins (IPC4) } & & $0.1465 *$ & & & & -0.0970 & & & & & \\
\hline & & {$[0.0570]$} & & & & {$[0.0601]$} & & & & & \\
\hline \multirow[t]{2}{*}{ New Functionality (IPC4) } & & & $0.6320 * *$ & & & $0.3785^{* *}$ & & & & & \\
\hline & & & {$[0.1011]$} & & & [0.1103] & & & & & \\
\hline \multirow[t]{2}{*}{ New Impact (IPC4) } & & & & $1.3608^{* *}$ & & $1.3654^{* *}$ & & & & & \\
\hline & & & & {$[0.0416]$} & & {$[0.0427]$} & & & & & \\
\hline Composite measure Radical (IPC4) & & & & & $1.2200^{* *}$ & -0.3115 & & & & & \\
\hline \multirow[t]{2}{*}{ New Origins (IPC6) } & & & & & & & $-0.1802 * *$ & & & & $-0.5134 * *$ \\
\hline & & & & & & & {$[0.0180]$} & & & & [0.0193] \\
\hline \multirow[t]{2}{*}{ New Functionality (IPC6) } & & & & & & & & $0.2393 * *$ & & & 0.0770 \\
\hline & & & & & & & & {$[0.0345]$} & & & {$[0.0581]$} \\
\hline \multirow[t]{2}{*}{ New Impact (IPC6) } & & & & & & & & & $1.0308^{* *}$ & & $1.1312^{* *}$ \\
\hline & & & & & & & & & {$[0.0151]$} & & {$[0.0156]$} \\
\hline \multirow[t]{2}{*}{ Composite measure Radical (IPC6) } & & & & & & & & & & $0.4073 * *$ & 0.0943 \\
\hline & & & & & & & & & & {$[0.0406]$} & {$[0.070011]$} \\
\hline Number of IPC3 classes & {$[0.0153]$} & [0.0153] & {$[0.015371]$} & [0.0153] & [0.0153] & {$[0.0154]$} & {$[0.0154]$} & {$[0.0153]$} & {$[0.0150]$} & [0.0153] & {$[0.0152]$} \\
\hline \multirow[t]{2}{*}{ Number of IPC4 classes } & $0.3409 * *$ & $0.3397^{* *}$ & $0.3394 * *$ & $0.3304 * *$ & $0.3405^{* *}$ & $0.3303 * *$ & $0.3444 * *$ & $0.3384^{* *}$ & $0.3127^{* *}$ & $0.3386^{* *}$ & $0.3204 * *$ \\
\hline & {$[0.0112]$} & {$[0.0112]$} & {$[0.0113]$} & {$[0.0113]$} & {$[0.0112]$} & {$[0.0113]$} & {$[0.0113]$} & {$[0.0112]$} & {$[0.0112]$} & {$[0.0113]$} & [0.0112] \\
\hline \multirow[t]{2}{*}{ Number of IPC6 classes } & 0.0056 & 0.0058 & 0.0053 & $0.0078^{*}$ & 0.0057 & 0.0075 & $0.0072^{*}$ & 0.0032 & -0.0030 & 0.0033 & -0.0004 \\
\hline & {$[0.0034]$} & {$[0.0034]$} & {$[0.0034]$} & {$[0.0035]$} & {$[0.0034]$} & {$[0.0035]$} & {$[0.0034]$} & {$[0.0034]$} & {$[0.0035]$} & {$[0.0034]$} & {$[0.0035]$} \\
\hline \multirow[t]{2}{*}{ Number of DOCDB family members } & $0.0581^{* *}$ & $0.0581^{* *}$ & $0.0580 * *$ & $0.0586 * *$ & $0.0581 * *$ & $0.0585^{* *}$ & $0.0578^{* *}$ & $0.0580 * *$ & $0.0620 * *$ & $0.0583 * *$ & $0.0616^{* *}$ \\
\hline & {$[0.0014]$} & {$[0.0014]$} & {$[0.0014]$} & {$[0.0014]$} & {$[0.0014]$} & {$[0.0014]$} & {$[0.0014]$} & {$[0.0014]$} & {$[0.0014]$} & {$[0.0014]$} & {$[0.0014]$} \\
\hline \multirow[t]{2}{*}{ Number of applicants } & $-0.1769 * *$ & $-0.1769 * *$ & $-0.1767^{* *}$ & $-0.1783^{* *}$ & $-0.1769 * *$ & $-0.1782^{* *}$ & $-0.1763^{* *}$ & $-0.1764 * *$ & $-0.1764^{* *}$ & $-0.1771^{* *}$ & $-0.1745^{* *}$ \\
\hline & {$[0.0157]$} & {$[0.0157]$} & {$[0.0157]$} & {$[0.0158]$} & {$[0.0157]$} & {$[0.0158]$} & {$[0.0157]$} & {$[0.0157]$} & {$[0.0158]$} & {$[0.0157]$} & {$[0.0155]$} \\
\hline \multirow[t]{2}{*}{ Number of inventors } & $0.1209 * *$ & $0.1210^{* *}$ & $0.1212^{* *}$ & $0.1223^{* *}$ & $0.1210 * *$ & $0.1223^{* *}$ & $0.1197^{* *}$ & $0.1214^{* *}$ & $0.1288^{* *}$ & $0.1218^{* *}$ & $0.1264 * *$ \\
\hline & {$[0.0035]$} & {$[0.0035]$} & {$[0.0035]$} & {$[0.0035]$} & {$[0.0035]$} & {$[0.0035]$} & {$[0.0035]$} & {$[0.0035]$} & {$[0.0035]$} & {$[0.0035]$} & [0.0035] \\
\hline \multirow[t]{2}{*}{ Number of backward citations } & $0.0300 * *$ & $0.0298^{* *}$ & $0.0300 * *$ & $0.0293 * *$ & $0.0299 * *$ & $0.0294^{* *}$ & $0.0313^{* *}$ & $0.0299 * *$ & $0.0252^{* *}$ & $0.0296 * *$ & $0.0286 * *$ \\
\hline & {$[0.0004]$} & {$[0.0004]$} & [0.0004] & {$[0.0004]$} & {$[0.0004]$} & {$[0.0004]$} & {$[0.0004]$} & {$[0.0004]$} & {$[0.0004]$} & {$[0.0004]$} & {$[0.000438]$} \\
\hline
\end{tabular}

Table 5: Coefficients of the logit regressions, robust standard errors are displayed in brackets. 


\section{References}

Acs, Z.J., Audretsch, D.B., (1990), The Determinants of Small-firm Growth in United-States Manufacturing, Applied Economics 22, pp. 143-153.

Ahuja, G., Lampert C.M., (2001), Entrepreneurship in the Large Corporation: A Longitudinal Study of How Established Firms Create Breakthrough Inventions, Strategic Management Journal 22, pp. 521543.

Anderson, P., Tushman, M.L., (1990), Technological Discontinuities and Dominant Designs - A Cyclical Model of Technological Change, Administrative Science Quarterly 35, pp. 604-633.

Arthur, W.B., (2007), The Structure of Invention, Research Policy 36, pp. 274-287.

Arthur, W. B. (2009). The Nature of Technology: What It Is and How It Evolves. Penguin Books.

Banerjee, P.M., Cole, B.M., (2011), Globally Radical Technologies and Locally Radical Technologies: The Role of Audiences in the Construction of Innovative Impact in Biotechnology, IEEE Transactions on Engineering Management 58, pp. 262-274.

Carlo, J.L., Lyytinen, K., Rose, G.M., (2012), A Knowledge-based Model of Radical Innovation in Small Software Firms, MIS Quarterly 36, pp. 865-895.

Carpenter, M. P., Narin, F., \& Woolf, P. (1981). Citation rates to technologically important patents. World Patent Information, 3(4), 160-163.

Chandy, R.K., Tellis, G.J., (1998), Organizing for Radical Product Innovation: The Overlooked Role of Willingness to Cannibalize, Journal of Marketing Research 35, pp. 474-487.

Chandy, R.K., Tellis, G.J., (2000), The Incumbent's Curse? Incumbency, Size and Radical Product Innovation, Journal of Marketing 64, pp. 1-17.

Christensen, C.M., Bower, J.L., (1996), Customer Power, Strategic Investment, and the Failure of Leading Firms, Strategic Management Journal 17, pp. 197-218.

Cooper, A.C., Schendel, D., (1976), Strategic Responses to Technological Threats, Business Horizons 19, pp. 61-69.

Dahlin, K.B., Behrens, D.M., (2005), When is an Invention Really Radical? Defining and Measuring Technological Radicalness, Research Policy 34, pp. 717-737.

Damanpour, F., (1996), Organizing Complexity and Innovation: Developing and Testing Multiple Contingency Models, Management Science 42, pp. 693-716.

Day, G.S., Fein, A.J., Ruppersberger, G., (2003), Shakeouts in Digital Markets: Lessons from B2B Exchanges, California Management Review 45, pp. 131+. 
De Brentani, U., (2001), Innovative Versus Incremental New Business Service: Different Keys for Achieving Success, Journal of Product Innovation Management 18, pp. 169-187.

Delgado-Verde, M., Emilio Navas-Lopez, J., Cruz-Gonzalez, J., et al., (2011), Radical Innovation From Relations-Based Knowledge: Empirical Evidence in Spanish Technology-intensive Firms, Journal of Knowledge Management 15, pp. 722-737.

Dewar, R.D., Dutton, J.E., (1986), The Adoption of Radical and Incremental Innovations - An Empirical Analysis, Management Science 32, pp. 1422-1433.

Dosi, G., (1982), Technological Paradigms and Technological Trajectories - A Suggested Interpretation of the Determinants and Directions of Technical Change, Research Policy 11, pp. 147-162.

Ehrnberg, E., (1995), On the Definition and Measurement of Technological Discontinuities, Technovation 15, pp. 437-452.

Ettlie, J.E., Bridges, W.P., Okeefe, R.D., (1984), Organization Strategy and Structural Differences for Radical Versus Incremental Innovtion, Management Science 30, pp. 682-695.

Fleming, L., (2001), Recombinant Uncertainty in Technological Search, Management Science 47, pp. 117132.

Fleming, L., (2007), Breakthroughs and the "Long tail" of Innovation, MIT Sloan Management Review 49, pp. 69+.

Gambardella, A., Harhoff, D., \& Verspagen, B. (2008). The value of European patents. European Management Review, 5(2), 69-84.

Garcia, R., Calantone, R., (2002), A Critical Look at Technological Innovation Typology and Innovativeness Terminology - A Literature Review, Journal of Product Innovation Management 19, pp. 110-132.

Gassmann, O., Von Zedtwitz, M., (2003), Trends and Determinants of Managing Virtual R\&D Teams, R\&D Management 33, pp. 243-262.

Gittelman, M., Kogut. B., (2003), Does Good Science Lead to Valuable Knowledge? Biotechnology Firms and the Evolutionary Logic of Citation Patterns, Management Science 49, pp. 366-382.

Hall, B. H., Jaffe, A.B, \& Trajtenberg, M. (2005). Market value and patent citations. RAND Journal of economics, 16-38.

Henderson, R., (1993), Underinvestment and Incompetence as Responses to Radical Innovation Evidence From the Photolithographic Alignment Equipment Industry, RAND Journal of Economics 24, pp. 248-270.

Henderson, R.M., Clark, K.B., (1990), Architectural Innovation - The Reconfiguration of Existing Product Technologies and the Failure of Established Firms, Administrative Science Quarterly 35, pp. 9-30. 
Hill, C.W.L., Rothaermel, F.T., (2003), The Performance of Incumbent Firms in the Face of Radical Technological Innovation, Academy of Management Review 28, pp. 257-274.

Hurmelinna-Laukkanen, P., Sainio, L.M., Jauhiainen, T., (2008), Appropriability Regime for Radical and Incremental Innovations, R\&D Management 38, pp. 278-289.

Leifer, R., O'Connor, G.C., Rice, M., (2001), Implementing Radical Innovation in Mature Firms: The Role of Hubs, Academy of Management Executive 15, pp. 102-113.

Lettl, C., Herstatt, C., Gemuenden, H.G., (2006), Learning From Users for Radical Innovation, International Journal of Technology Management 33, pp. 25-45.

Majchrzak, A., Cooper, L.P., Neece, O.E., (2004), Knowledge Reuse for Innovation, Management Science 50, pp. $174-188$.

Mascitelli, R., (2000), From Experience: Harnessing Tacit Knowledge to Achieve Breakthrough Innovation, Journal of Product Innovation Management 17, pp. 179-193.

Nahm, A. Y., Vonderembse, M. A., \& Koufteros, X. A. (2003). The impact of organizational structure on time-based manufacturing and plant performance. Journal of Operations Management, 21(3), 281306.

Nemet, G.F., (2009), Demand-pull, Technology-push, and Government-led Incentives for Nonincremental Technical Change, Research Policy 38, pp. 700-709.

Nerkar, A., (2003), Old is Gold? The Value of Temporal Exploration in the Creation of New Knowledge, Management Science 49, pp. 211-229.

Nooteboom, B., (2000), Institutions and Forms of Co-ordination in Innovation Systems, Organization Studies 21, pp. 915-939.

O’Reilly, C.A., Tushman, M.L., (2004), The Ambidextrous Organization, Harvard Business Review 82, pp. $74+$.

Phene, A., Fladmoe-Lindquist, K., Marsh, L., (2006), Breakthrough Innovations in the US Biotechnology Industry: The Effects of Technological Space and Geographic Origin, Strategic Management Journal 27, pp. 369-388.

Ritala, P., Hurmelinna-Laukkanen, P., (2013), Incremental and Radical Innovation in Coopetition - The Role of Absorptive Capacity and Appropriability, Journal of Product Innovation Management 30, pp. 154-169.

Rosenkopf, L., Nerkar, A., (2001), Beyond Local Search: Boundary-spanning, Exploration, and Impact in the Optical Disk Industry, Strategic Management Journal 22, pp. 287-306.

Rothaermel, F.T., Hill, C.W.L., (2005), Technological Discontinuities and Complementary Assets: A Longitudinal Study of Industry and Firm Performance, Organization Science 16, pp. 52-70. 
Schoenmakers, W., Duysters, G., (2010), The Technological Origins of Radical Inventions, Research Policy 39, pp. 1051-1059.

Schumpeter, J.A., (1939), Business Cycles: A Theoretical, Historical and Statistical Analysis of the Capitalist Process.

Shane, S., (2001), Technological Opportunities and New Firm Creation, Management Science 47, pp. 205-220.

Singh, J., Fleming, L., (2010), Lone Inventors as Sources of Breakthroughs: Myth or Reality?, Management Science 56, pp. 41-56.

Story, V., O’Malley, L., Hart, S., (2011), Roles, Role Performance and Radical Innovation Competences, Industrial Marketing Management 40, pp. 952-966.

Trajtenberg, M., Henderson, R., \& Jaffe, A. (1997). University versus corporate patents: A window on the basicness of invention. Economics of Innovation and new technology, 5(1), 19-50.

Tripsas, M., (1997), Unraveling the Process of Creative Destruction: Complementary Assets and Incumbent Survival in the Typesetter Industry, Strategic Management Journal 18, pp. 119-142.

Tushman, M.L., Anderson, P., (1986), Technological Discontinuities and Organizational Environments, Administrative Science Quarterly 31, pp. 439-465.

Veryzer, R.W., The Roles of Marketing and Industrial Design in Discontinuous New Product Development, Journal of Product Innovation Management 22, pp. 22-41.

Wheelwright, S.C., Clark, K.B., (1992), Creating Project Plans to Focus Product Development, Harvard Business Review 70, pp. 70-82. 
FACULTY OF ECONOMICS AND BUSINESS DEPARTMENT OF MANAGERIAL ECONOMICS, STRATEGY AND INNOVATION Naamsestraat 69 bus 3500 3000 LEUVEN, BELGIË tel. +3216326700 $\mathrm{fax}+3216326732$ info@econ.kuleuven.be www.econ.kuleuven.be/MSI 